The Quarterly Journal of Austrian Economics

Volume 23 | NO. 3-4 | 313-354 | FALL/Winter 2020 WWW.QJAE.ORG

\title{
Austrian ECONOMics AND Organizational ENTREPRENEURSHIP: A TyPology
}

\author{
Sara R. S. T. A. Elias, Todd H. Chiles, Qian Li, Fernando \\ Antonio Monteiro Christoph D’Andrea*
}

JEL Classification: B53, D24, D50, D81, L26, M10

AвSTRACT: This article develops a typology for making sense of the numerous strands of Austrian (and Austrian-related) economics and demonstrates how this typology can guide organizational entrepreneurship scholars wishing to ground their research in Austrian thought. In the process, not only are existing insights from the history of Austrian economic thought rediscovered, but clearer light is also shed on important perspectives from that tradition that have received less attention in entrepreneurship

\footnotetext{
*Sara R. S. T. A. Elias (selias@uvic.ca) is an assistant professor of entrepreneurship at the University of Victoria's Peter B. Gustavson School of Business and a research associate of the Center for Psychosocial Organization Studies.

Todd H. Chiles (chilest@missouri.edu) is a senior research fellow at the Center for the Study of Complexity, Creation and Change and an emeritus professor at the University of Missouri's Trulaske College of Business.

Qian Li (qian.li.5@cass.city.ac.uk) is a PhD candidate at the Cass Business School, City, University of London.

Fernando A. Monteiro C. D'Andrea (fernando.dandrea@okstate.edu) is a PhD student in entrepreneurship at the Spears School of Business, Oklahoma State University.

The authors thank Joseph T. Salerno and two anonymous reviewers who helped them sharpen their thinking and refine their arguments, as well as the special issue guest editor, Per Bylund, for his encouragement and thoughtful guidance throughout the review process.
} 
research. Based on the Austrian concept of entrepreneurial production and its relationship with the core concepts of knowledge and change, the typology yields four perspectives-equilibration, punctuated equilibrium, disequilibration, and punctuated disequilibrium. These perspectives' different paradigms as used in organizational research are explored, along with their ontological, epistemological, and methodological assumptions. The typology is illustrated with selected empirical examples from organizational research to spotlight the types of questions that contemporary scholars may appropriately ask and answer from each perspective.

\section{INTRODUCTION}

ustrian economics, which will celebrate its sesquicentennial in ideas (Ekelund and Hébert 2014), and its proponents have played a particularly important role in building the economic foundations of entrepreneurship (Hébert and Link 2006). More recently, it has become a central pillar of organizational entrepreneurship research, featured in theoretical (Cheah 1990; Chiles, Tuggle, et al. 2010; Dew, Velamuri, and Venkataraman 2004; Mathews 2010; McMullen and Shepherd 2006), empirical (Chiles, Meyer, and Hench 2004; Chiles et al. 2013; Dean and Meyer 1996; Dolmans et al. 2014; Keyhani and Lévesque 2016; Shane 1996 2000), and programmatic (Chiles, Bluedorn, and Gupta 2007; Chiles, Vultee, et al. 2010; Foss and Klein 2012; Shane and Venkataraman 2000) work. As a school of economic thought to which many have contributed over a century and a half, Austrian economics is not a monolithic bloc; rather, it comprises a number of distinct strands or perspectives (McMullen and Shepherd 2006) - each with a unique ability to help scholars understand certain phenomena. Many organizational entrepreneurship scholars, however, appear to be unaware of this intellectual heterogeneity, leading some to unwittingly commingle concepts from different perspectives, unknowingly shoehorn ideas from one perspective into another, or simply ignore other perspectives altogether (Chiles, Bluedorn, and Gupta 2007). Consequently, the organizational entrepreneurship literature that draws from the Austrian tradition often contains inconsistencies and gaps.

This article takes a step toward addressing these problems by developing a typology that builds on Chiles, Vultee, et al. (2010) to make sense of the numerous strands of Austrian and Austrian-related economics, with a particular focus not on how the 
Austrian literature itself has developed, but on how it has inspired organizational research. Consistent with the wider organization studies literature, this article takes a broad view of Austrian economics to include not only its core thinkers (F. A. Hayek, Israel M. Kirzner, Ludwig M. Lachmann, Carl Menger, Ludwig von Mises, Murray N. Rothbard), but also closely related scholars such as Joseph A. Schumpeter ${ }^{1}$ and G.L.S. Shackle. ${ }^{2}$ Based on the Austrian school's emphasis on the entrepreneurial organizing of production in service of the consumer, and the relationship between production and the core Austrian concepts of knowledge and change, the typology elaborated here yields four distinct perspectives: two firmly rooted in states of equilibrium (equilibration and punctuated equilibrium $)^{3}$ and two that break sharply with the first perspective

\footnotetext{
${ }^{1}$ Although few (perhaps no) Austrian economists would count Schumpeter among their ranks, most organizational scholars would. Indeed, organizational scholars tend to see Schumpeter as "the preeminent Austrian economist" (see Chiles, Bluedorn, and Gupta 2007, 488). This view of Schumpeter as an Austrian economist probably obtains from his close ties to the Austrian school (e.g., Böhm-Bawerk supervised his dissertation, Wieser had a significant intellectual influence on him and vice versa; see Powell, Rahman, and Starbuck 2010) and his pursuit of Austrian themes (Vaughn 1994). For more on Schumpeter and his relationship to Austrian economics, see Ekelund and Hébert (2014), who cover Schumpeter in their chapter on "Austrian Economics."

${ }^{2}$ Shackle studied Austrian economics under Hayek and completed his dissertation under his supervision (Harcourt 1981, 139-40), albeit on a Keynesian topic. Consequently, some consider Shackle a post-Keynesian with Austrian school influences. Shackle later explored issues raised by Mises about the fundamentally indeterminate nature of a social science of human action, developed innovative subjectivist theory that engaged Austrian ideas and laid the groundwork for further Austrian research, and served as an ally to Austrian economists interested in radical subjectivism (Vaughn 1994, 75, 104, 118). In a 1978 interview, Lachmann was asked what relationship he saw between Shackle's work and that of the Austrian school. His response: "I can think of no one more distinguished or important to the fundamental Austrian ideas than Shackle ... I regard Shackle as, in fact, an Austrian" (Lachmann 1978). So too have organizational entrepreneurship scholars who draw on Austrian radical subjectivism (Chiles et al. 2013; Chiles, Tuggle, et al., 2010; Chiles, Vultee, et al. 2010; McMullen 2010).

${ }^{3}$ The concept(s) of equilibrium in the Austrian tradition differs substantially from what is commonly seen in mainstream economics-and is usually taken for granted by organizational scholars-either in the general or the partial equilibrium tradition. Unless otherwise noted, the word equilibrium in this paper refers to the Austrian concept of the Wicksteedian state of rest (WSR), which, along with other Austrian ideas, is explained below in the section entitled "Core Concepts in Austrian Economics."
} 
(disequilibration and punctuated disequilibrium). The goal is to help scholars pursue Austrian-inspired organizational entrepreneurship research in a more mindful and informed manner by providing not only an organizing scheme to make sense of the various strands of Austrian economics, but also a nuanced understanding of how each of those strands maps onto different ontological, epistemological, and methodological assumptions.

This is important because different strands of Austrian economics are undergirded by different philosophical assumptions, which play a powerful role in how we see and study entrepreneurial phenomena (Chiles, Vultee, et al. 2010; McMullen and Shepherd 2006). Indeed, different paradigms are appropriate for understanding particular phenomena and pursuing certain lines of inquiry - and not others (Burrell and Morgan 1979). Thus, the aim is to sensitize organizational entrepreneurship scholars wishing to ground their work in Austrian thought to the importance of the different ontological, epistemological, and methodological assumptions within this school as used in organizational research.

This article goes beyond previous efforts by organizational entrepreneurship scholars to make sense of Austrian ideas. For example, Pittaway (2005) summarized the philosophical assumptions of a wide range of economic approaches to organizational entrepreneurship, including Austrian economics, but treated the Austrian school as a monolith. Jeffery S. McMullen and Dean A. Shepherd (2006) focused on the philosophical assumptions of Frank H. Knight, Kirzner, and Schumpeter but did not develop an overarching typology. Chiles, Vultee, et al. (2010) explored the philosophical and methodological assumptions of neoclassical and Austrian economics approaches to organizational entrepreneurship. Although they distinguished different strands of Austrian thought, they used a single, generic objective-subjective dimension to structure their arguments, an approach criticized by some scholars (Cunliffe 2011). Although drawing inspiration from Chiles, Vultee, et al. (2010), for example, in how the typology's perspectives were titled, this work, by contrast, builds upon the fundamental Austrian idea of production as guided by the entrepreneur (Lachmann 1976; Mises [1949] 1998; Rothbard [1962, 1970] 2009) and its relationship with the core concepts of knowledge (convergent / divergent) and change (continuous / discontinuous). Further, this work explores different Austrian constructs 
of equilibrium to understand markets as dynamic, real-world processes, thus providing a more comprehensive view; it does so in order to develop a typology that links each type to the broader philosophical and methodological assumptions of organizational research commonly conducted using that perspective. This typology contributes to the field of organizational entrepreneurship by not only allowing scholars to make sense of a wide range of entrepreneurial phenomena, but also guiding them to the best approach in studying the particular phenomena of interest to them.

In sum, the aim of this work is to provide guidance to organizational entrepreneurship scholars wishing to ground their research in Austrian thought. It does so by first reviewing the core concepts of equilibrium, knowledge, and change within the Austrian school of economics and explaining how these concepts have been used to develop a typology that makes sense of the numerous perspectives within this school. Next, it is shown how the typology's perspectives are all rooted in different sets of philosophical and methodological assumptions, and why this matters to Austrian-inspired organizational entrepreneurship research. In addition, the typology is illustrated using selected empirical examples drawn from the organization studies literature-all comprising an industry level of analysis-in order to spotlight the types of questions that entrepreneurship scholars can appropriately ask and answer from each perspective. The nature of the entrepreneur and of opportunities is also discussed in relation to each perspective, with the aim of helping organizational entrepreneurship scholars locate and choose the most appropriate perspective for their research efforts. Finally, organizational entrepreneurship researchers are provided with potential research questions that are illustrative of the types of phenomena with which each Austrian perspective is concerned.

\section{A TYPOLOGY FOR CLASSIFYING AUSTRIAN IDEAS IN ORGANIZATIONAL ENTREPRENEURSHIP RESEARCH}

Typologies allow scholars to order and make sense of phenomena by arranging information into distinct and somewhat homogeneous groups. The categorization of information and patterns is essential to 
advance social theory and research, because classifying knowledge into homogeneous categories allows us to find differences between phenomena and to, ultimately, understand existing commonalities (Meyer, Tsui, and Hinings 1993). Each of the four quadrants of the typology presented here is rooted in specific philosophical assumptions that correspond to particular insights and ideas in which one can base future research in entrepreneurship. As such, each quadrant provides a focused way for organizational scholars to use an Austrian economics lens to make sense of entrepreneurship phenomena. These four quadrants correspond to three different paradigms, which denote different views of reality (Morgan 1980). Following Robert K. Merton (2004, 267), the term paradigm is used "to refer to exemplars of codified basic and often tacit assumptions, problem sets, key concepts, logic or procedure, and selectively accumulated knowledge that guide inquiry in all scientific fields." In other words, paradigms are viewed as worldviews rooted in basic sets of beliefs that guide action (Creswell 2007). As Thomas Kuhn (1970) argued, paradigms have both intellectual and social purposes. First, they guide researchers to new definitions and questions about phenomena and, second, they "form structures within which their members can share a sense of purpose and engage in day-to-day practices of collaboration, collegiality, and 'progress'” (Lindlof and Taylor 2011, 33).

In research, paradigms allow scholars to develop high-quality research designs by providing them with a set of philosophical assumptions regarding "the nature of reality (ontology), how the researcher knows what she or he knows (epistemology), the role of values in the research (axiology), the language of research (rhetoric), and the methods used in the process (methodology)" (Creswell 2007, 16). These philosophical stances shape the phenomena studied, the types of problems and questions posed, the particular approaches to data collection/generation and analysis, as well as the type of language used to describe and disseminate information (Creswell 2007). In this paper, the ontology, epistemology, and methodology of each paradigm are explored as a means to improve clarity regarding — and ultimately provide guidance on-how Austrian economics can be used as a lens to understand entrepreneurship phenomena. 


\section{CORE CONCEPTS IN AUSTRIAN ECONOMICS}

At the essence of the Austrian school of economics is praxeology, a term developed by Mises ([1949] 1998). Praxeology refers to the science of human action, i.e., the conscious actions taken by individuals toward a chosen goal. As such, it "rests on the fundamental axiom that individual human beings act" (Rothbard 1997, 58), with action consisting of the processes by which one selects a particular alternative over another by using specific means to pursue desired ends (Vaughn 1994). Fundamental to an understanding of human action is the notion that an individual's actions take place over time (Mises [1949] 1998) and that his/her choices are rooted in knowledge that is only known to that individual (Hayek 1945). In the realm of entrepreneurship, Austrian economics treats the individual (i.e., the entrepreneur) as an organizer of production processes (Bylund 2016; Lachmann 1976; see also Mises [1949] 1998; Rothbard [1962, 1970] 2009). It is in production processes subject to unexpected change-which by their nature require individuals to combine and continually recombine resourcesthat "we find the real function of the entrepreneur" (Lachmann 1956, 13). Consistent with Austrian precepts, such processes take time to play out and are bounded by the entrepreneur's limited knowledge (or ignorance).

Because Austrian economics places entrepreneurs at the very core of the market process, it is commonly referred to as the economics of time and ignorance (Vaughn 1994, 134)—a term that derives from John Maynard Keynes's $(1964,155)$ "dark forces of time and ignorance," which point out "the importance of the basic problems with which real time confronts individual actors" (O'Driscoll and Rizzo 1996, xiv). Although Keynes was quite far from being an Austrian, as a neoclassical economist he did use subjectivist elements in his economic analyses. The Austrian school of economics is rooted in dynamic subjectivism, as opposed to the static subjectivism of neoclassical economics. Unlike static subjectivism, dynamic subjectivism recognizes creativity and the uncertain nature of human action that unfolds through processes of change (Vaughn 1994). To study this dynamism, Austrian scholars have developed different ways of thinking about equilibrium. 


\section{EQUILIBRIUM}

The Austrian school recognizes the market as a dynamic process that is always in disequilibrium. Thus, contrary to mainstream views, it does not use a single theoretical idea of static equilibrium; rather, it uses different dynamic equilibrium-like constructs to understand and deal with market dynamism. Recent work by Per Bylund (2019) recognizes this flawed use of static equilibrium in Austrian theorizing while problematizing Kirzner. Three of these Austrian equilibrium-like constructs are purely theoretical: (1) The evenly rotating economy, or ERE (Rothbard [1962, 1970] 2009), an imaginary construction where changes in preference and satisfaction are held constant while human action persists but merely as repetitive routine (Packard 2019, 6). (2) The final state of rest, or FSR, toward which all action is "pulled" and where there would be no action because all dissatisfaction would disappear; this state, however, "is constantly changing, as preferences, knowledge, technology, and expectations shift over time" and is thus never reached (Mises [1949] 1998; Packard 2019, 5). (3) The "Nirvana state of rest," or NSR, in which all action becomes unnecessary because "no future knowledge, technology, or resources can attain a higher state of well-being; all possible improvements (forevermore) have been exploited, and we are at a true optimal state" (Packard 2019, 9). These equilibrium constructs, which are hypothetical, are theoretically similar to the mainstream concept of equilibrium (i.e., absence of new production and lack of change in the subjective valuations of market participants), which is, by definition, static. Austrian ideas about equilibrium, which are rooted in very different underlying assumptions, are fundamentally based on a market process that constantly reaches some kind of temporary equilibrium but that is dynamic in nature. Being hypothetical, these constructs serve only for economic reasoning and thus are not helpful to this discussion.

Two additional equilibrium constructs that appear in Austrian theorizing and that are more closely related to this discussion because they are grounded in the real world are: (1) the plain state of rest, or PSR, and (2) the fully arbitraged state of rest, or Wicksteedian state of rest, WSR (Packard 2019; Salerno 1994). The first state, the PSR, is reached every single time an exchange takes place, when all parties in a transaction momentarily exhaust the possible 
gains from trade. It is a momentary equilibrium that persists so long as "the prevailing state of valuations of the marginal pairs in each market remain constant" (Salerno 1994, 97-98). It is reached in a given market, at a given time, when all trades have been temporarily satisfied. At that particular time, all buyers and sellers have carried out the transactions that they deemed satisfactory at the current prices, to the point when everyone in the market is satisfied with the current situation and sees no reason to pursue further exchanges (Mises [1949] 1998, 245-251). ${ }^{4}$ The second state, the WSR, is more general; it is based on Wicksteed's idea of the fruit market, in which the stocks of perishable goods and consumer valuations remain fixed for a given, foreseeable duration. It was reintroduced in Austrian circles by Joseph T. Salerno (1994) as a state between the FSR and the PSR. A WSR is reached "when preferences, supplies, and available parties to trade remain constant over some period of time" (Packard 2019, 6). This state lasts for as long as the prices for all goods in a given market remain stable; "[f]or the rest of the market day, each successive set of transactions takes place at equilibrium prices and thus generates a momentary WSR until the arrival of the next group of buyers on the scene" (Salerno 1994, 100).

Unlike in a PSR, where prices may change moment after moment, in a WSR, the different market criteria are stable enough to keep an equilibrated price and to get rid of arbitrage opportunities for a given period of time in a given place. An example of a situation close to a WSR is supermarket prices, which remain stable even after numerous transactions and end up facilitating exchanges because of price stability. This price stability is the basic idea behind general equilibrium. Figure 1 shows different understandings of equilibrium in terms of Austrian equilibrium constructs, real-world market equilibria, and mainstream equilibrium constructs.

\footnotetext{
${ }^{4}$ In some specific empirical cases, there may be a theoretical difference between initial price paid or agreed upon by parties and the actual PSR (two-party marketclearing) price. However, this analysis falls outside the scope of this paper and thus does not affect our argument.
} 
Figure 1. Different Understandings of Equilibrium: Comparisons and Rough Equivalences

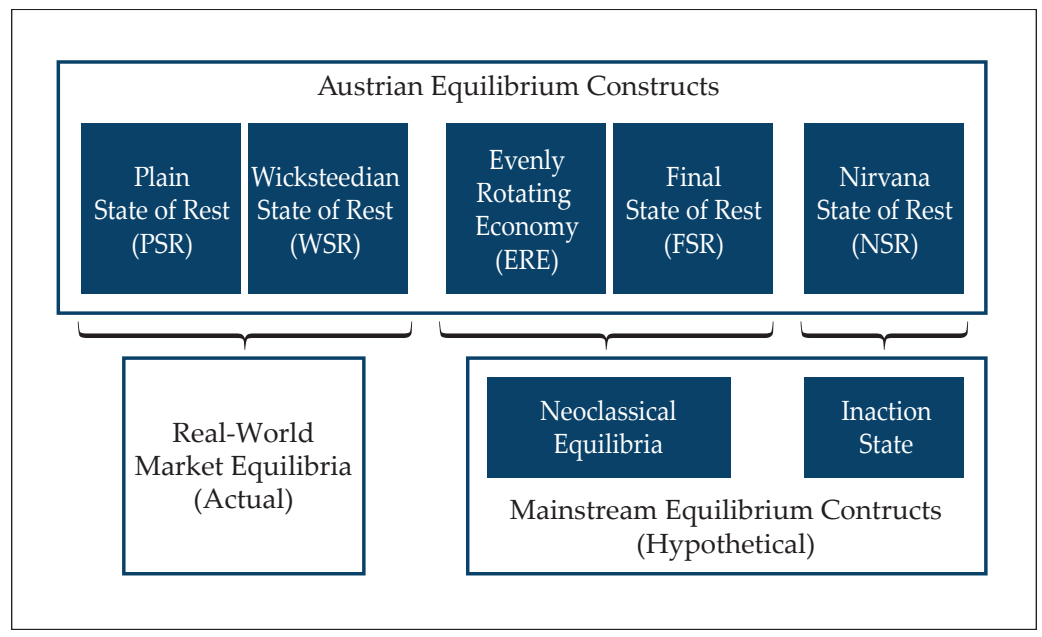

Significantly, the equivalences in figure 1 between Austrian and mainstream equilibrium constructs are neither perfect nor possible. The reason for this is that, for example, neoclassical economics does not aim to explain market prices, but rather hypothetical prices (as in full information, Nash equilibrium, perfect competition, etc.). As has been seen, the Austrian approach differs substantially from the neoclassical one in that it seeks to explain real-world prices (Klein 2008; Manish 2014). The aim with figure 1 is simply to facilitate understanding of Austrian ideas by comparing them to real-world market equilibria and mainstream equilibrium constructs.

In short, in discussions of entrepreneurship and production, Austrian economics recognizes two variants of real-world equilibrium-the PSR and WSR. The typology presented here is grounded in the latter, because entrepreneurial action starts at a point close to the WSR, eventually moving markets either closer or farther away from equilibrium. Furthermore, according to proponents of the Austrian school, "economics should be about how humans pursue their projects and plans over time, and with limited knowledge of present conditions and with pervasive uncertainty about the future" (Vaughn 1994, 4; see also Lachmann 1976 and Rothbard [1962, 1970] 2009). Thus, Austrians also recognize 
that equilibrium situations occur based on two important concepts: ignorance (or limited knowledge of the parts involved) and time (or the passage of time required for production to yield consumer goods-a process that relates to change). Discussed in the next two subsections are the typology's dimensions-two core concepts that are central to the entrepreneurial organizing of production: knowledge (as convergent or divergent) and change (as continuous or discontinuous).

\section{Knowledge}

While neoclassical economists tend to assume perfect and homogeneous knowledge in the processes of decision-making and acting, Austrian economists view knowledge as imperfect, heterogeneous, complex, disaggregated, and dispersed (Vaughn 1994), as well as tacit and local (Hayek 1945). This conception of knowledge lets us understand why for Austrians human action will always result in unintended and uncertain outcomes. Uncertainty is one of the basic tenets of Austrian economics and is also a corollary of ignorance (O'Driscoll and Rizzo 1996). Thus, an understanding of ignorance, or limitation of knowledge, is crucial in Austrian thought.

Hayek, in his seminal paper "The Use of Knowledge in Society," developed an understanding of knowledge not in terms of general laws, but rather "the particular circumstances of time and place" (Hayek 1945, 521). Later he further broadened understanding of knowledge in economic analyses by characterizing knowledge as "private, empirical, often tacit, not all gained through price signals, and often the source of surprise" (O'Driscoll and Rizzo 1996, 102). Hayek's characterization of knowledge as tacit was based on Michael Polanyi's ideas (Gourlay 2006). For Polanyi, knowledge has a fundamental and indispensable tacit component, even so-called scientific knowledge. Indeed, he suggests "that into every act of knowing there enters a passionate contribution of the person knowing what is being known, and that this coefficient is no mere imperfection but a vital component of his knowledge" (Polanyi 1958, viii). Despite Hayek's attempts to expand our understanding of knowledge, the definition of this concept remains rather vague. For instance, although Hayek (1945) argued that knowledge is a function of the "man on the spot" and that fragmented and tacit 
knowledge is coordinated through the market process (GloriaPalermo 1999), he did not make explicit what knowledge actually is. This has provided scholars within the Austrian school with the freedom to develop their interpretations of the concept, as can be seen in the knowledge arguments made by Kirzner, Schumpeter, and Lachmann.

More specifically, Kirzner (2005) distinguishes action knowledge from information knowledge. While action knowledge refers to the knowledge that shapes actions, information knowledge is what allows entrepreneurs to grasp opportunities. As Kirzner $(2005,80)$ notes, "The one who grasped the opportunity was, presumably through his alertness." For Kirzner (2005), it is alertness that transfers information knowledge into action knowledge and, given the economic role of advertising and learning, information knowledge tends to be convergent. For Schumpeter, unique and idiosyncratic knowledge arises from technological breakthroughs (Sarkar et al. 2006). Innovation entails new knowledge, which is imitated or modified by the swarm of new market entrants who are incentivized by the monopolistic profits generated by innovators. This eventually results in knowledge, manifested as innovation, moving toward convergence (see Packard and Bylund 2018). Finally, Lachmann's interpretation of knowledge contrasts starkly with Kirzner's and Schumpeter's. Lachmann considers knowledge as both interpretations of past experience and expectations of future action (Gloria-Palermo 1999). As such, knowledge is continually changing because of the "continual interpretation and re-interpretation of experience" and the "continual forming and re-forming of expectations," which "makes accurate prediction of the future not merely difficult but largely impossible" (Chiles, Bluedorn, and Gupta 2007, 483). Thus, for Lachmann, knowledge is divergent given that the idiosyncratic knowledge possessed by individuals is not easily reconciled and that these individuals have the ability to create, in their minds, divergent expectations of the future.

In short, for some Austrians, such as Hayek and Kirzner, the market process allows for the coordination of fragmented and tacit knowledge (Gloria-Palermo 1999). For others, such as Lachmann, when one incorporates past knowledge and future expectations, which are subjective, the result is knowledge divergence that prevents plan coordination (Chiles, Bluedorn, and Gupta 2007). 
This shows that within the broad tradition of the Austrian school of economics there are two opposing views of knowledge and how it changes over time. Based on these two opposing views, this article breaks the knowledge dimension down into a convergence-divergence dichotomy, represented horizontally in the typology.

\section{Change}

When Austrians acknowledge the temporal dimension of market processes, they implicitly accept the existence of change. Indeed, as shown above, change and knowledge are natural bedfellows in the market process: change can either lead to a convergence or divergence of knowledge. Thus, knowledge is not a static concept, but one that changes over time. Such changes in knowledge are the result of the human experience of time and, ultimately, of learning (Hayek 1945; Vaughn 1994). Change, which is a constant in a world composed of humans acting upon their plans, has been described as either a continuous or discontinuous process. Continuous change, or first-order change, occurs in stable systems that do not suffer abrupt modification. This type of change, as Haridimos Tsoukas and Robert Chia $(2002,567)$ have argued, is "the reweaving of actors' webs of beliefs and habits of action to accommodate new experiences obtained through interactions." Using the metaphor of the acrobat on a high wire, they explain that stability is maintained by continuously correcting one's imbalance (Tsoukas and Chia 2002). In Austrian economics, this relates to Kirzner's (1973) view of a world in continuous change directed to a FSR, always coming to different PSRs and moving toward a WSR.

On the other hand, discontinuous change, or second-order change, entails abrupt shifts in the state of the existing system, resulting in the inexistence of equilibrium on the horizon. For instance, Shackle suggests that market processes go through abrupt and unexpected change in what he calls a kaleidic society-one "in which sooner or later unexpected change is bound to upset existing patterns" (Lachmann 1976, 54); this is a society "interspersing its moments or intervals of order, assurance and beauty with sudden disintegration and a cascade into a new pattern" (Shackle 1972, 76). Further, Schumpeter views change as a process of creative destruction in which entrepreneurs create new resource 
combinations in a discontinuous manner (Schumpeter 1934) and in response to changes in technical knowledge (Schumpeter 1942; Shane 1996). Thus, for authors such as Schumpeter and Shackle, change takes place in a discontinuous manner rather than in a continuous way, as argued by Mises and Kirzner (see D'Andrea and Mazzoni 2019). Based on these two differing views, the change dimension can be broken down into a continuous-discontinuous dichotomy, represented vertically in the typology.

\section{A TYPOLOGY BASED ON KNOWLEDGE AND CHANGE}

The typology presented in this article illustrates four different perspectives within the Austrian school of economics broadly understood. Although four different perspectives are proposed, only three different paradigms - each with its specific ontological, epistemological, and methodological assumptions-underlie these perspectives. As explained above, ontology refers to the nature of reality, epistemology asks how the researcher knows what s/ he knows, and methodology describes the methods used in the research process (Creswell 2007). The assumptions stemming from each one of the perspectives presented in this typology are based on a combination of insights relating to alternative paradigms guiding research, as suggested by Guba and Lincoln (2005) and Chiles, Vultee, et al. (2010). The names of the perspectives represented in this typology are based on the forces that propel the market process: equilibration, disequilibration, punctuated equilibrium, and punctuated disequilibrium. For example, the convergence of knowledge will tend to generate a convergence of action from both entrepreneurs and consumers and, consequently, a tendency toward equilibrium; conversely, when knowledge is divergent, there will be a tendency toward disequilibrium. Figure 2 depicts the typology, with its two dimensions of knowledge and change and its four perspectives. It includes the major Austrian economists who are associated withand inspire organizational work within-each perspective, as well as information regarding the type of paradigm, ontology, epistemology, methodology, research exemplar, and entrepreneurship authors specific to each different perspective. Below the typology's four perspectives are explained in greater depth. 


\section{Figure 2. A Typology of Four Austrian Perspectives for Entrepreneurship Research: Key Austrian Economists, Paradigm, Ontology, Epistemology, Methodology, Empirical Examples, and Entrepreneurship Authors}

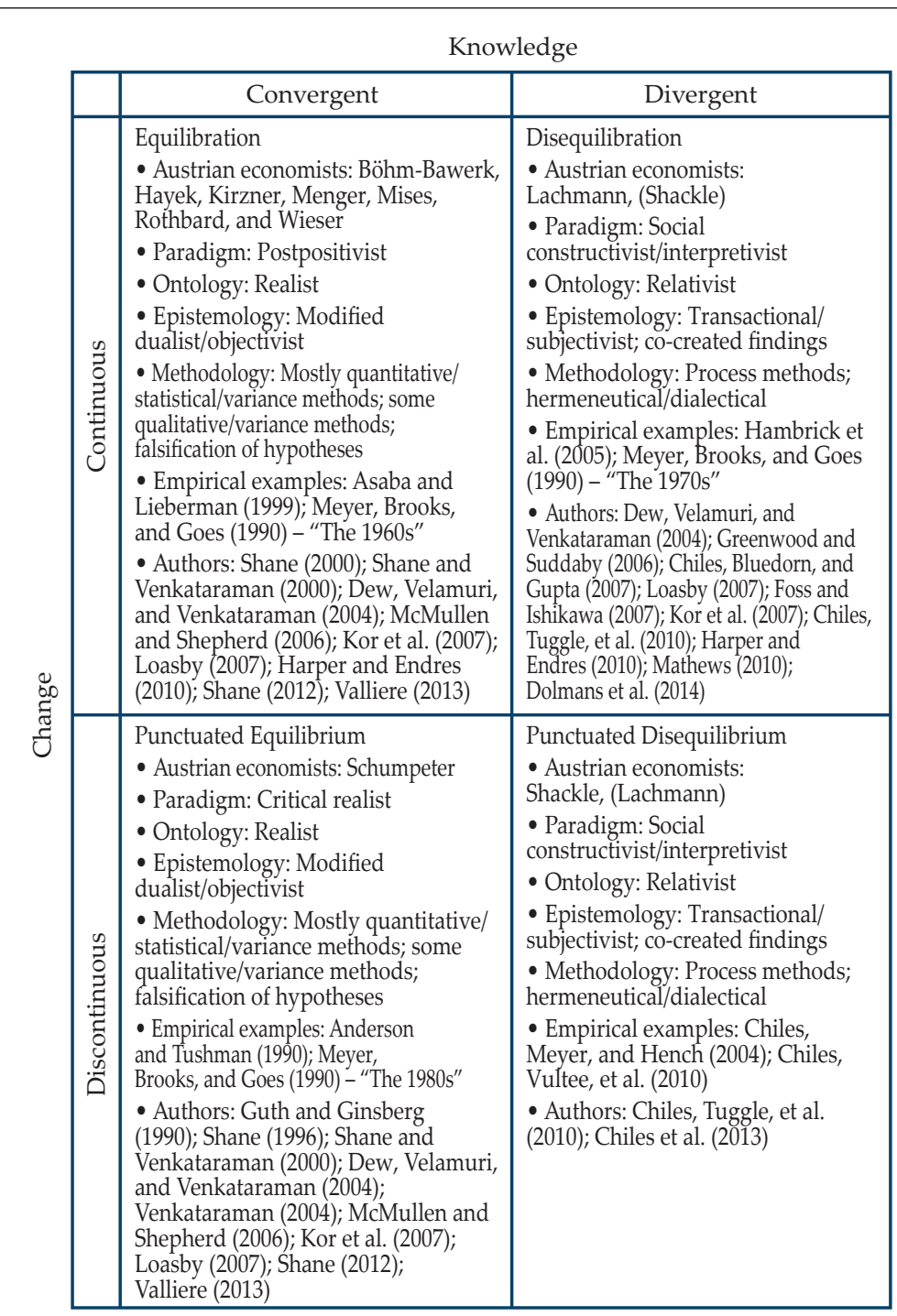




\section{Equilibration}

In this perspective, the entrepreneur is described as an equilibrator who drives the market process "towards the hypothetical state of equilibrium" (Kirzner 2009, 145), the FSR or the ERE, as explained above. In fact, entrepreneurs and their decisions and actions are viewed as playing a critical role in equilibrating market movements. As such, entrepreneurship is about how entrepreneurs' decisions disturb the existing market order-a process that emerges from entrepreneurs' alertness (Kirzner 2009)—and drive the market closer and closer to the ERE. Thus, driving the market process are alert entrepreneurs who continually discover preexisting opportunities according to "their subjective interpretation of past experience" (Chiles, Vultee, et al. 2010, 140)—opportunities that exist "out there" and that are merely "waiting to be noticed" (Kirzner 1973, 74). As a result of the exploitation of these opportunities and the forces of equilibration (Kirzner 1997), markets have a general and natural tendency to gravitate toward a state of equilibrium (Chiles, Bluedorn, and Gupta 2007). However, this state is never reached, as this would entail the unrealistic case of having no opportunities and no competition (Kirzner 1973 1997). Instead, the WSR keeps changing moment after moment for the various economic goods in the different geographical markets. Thus, in the equilibration perspective, entrepreneurs continually discover preexisting opportunities that they then exploit, allowing them to "correct market inefficiencies" and "coordinate dispersed knowledge" (Chiles, Vultee, et al. 2010, 142), driving markets closer and closer to the WSR. This perspective is characterized by continuous change and convergent knowledge. Key Austrian economists taking an equilibration perspective include Böhm-Bawerk, Hayek, Kirzner, Menger, Mises, Rothbard and Wieser.

The equilibration perspective is rooted in a postpositivist paradigm. Significantly, although Austrian economics uses axioms and logical deduction, it does not embrace postpositivism to generate theoretical insights. Yet organizational work that draws from equilibration's key Austrian thinkers is generally grounded in this paradigm, thus taking a scientific approach to research; as such, it tends to be reductionist, logical, deterministically based on a priori theories, with an emphasis on data collection and 
cause-effect oriented (see Creswell 2007). In practice, postpositivist scholars pursue research in a series of logically related steps by using rigorous methods of data collection and analysis while allowing for multiple levels of data analysis and using validation approaches. Additionally, they do not believe in a single reality; rather, they are on the lookout for participants' multiple perspectives (Creswell 2007). Specifically, entrepreneurship research based on a postpositivist paradigm is characterized by a realist ontology, relating to fairly objectivist philosophical assumptions (Chiles, Vultee, et al. 2010); a modified dualist/objectivist epistemology, in which findings are considered to be probably true (Guba and Lincoln 2005); and a mostly quantitative/statistical/variance methodology, although it may include some qualitative methods (Chiles, Vultee, et al. 2010; Guba and Lincoln 2005).

An example of an empirical study taking an equilibration perspective is Asaba and Lieberman (1999). In their study of the Japanese soft drink industry, the authors explore the underlying causes and mechanisms relating to increased behavior similarity among competing firms. In the Japanese soft drink industry, new products are quickly followed by imitations from competitors. This mimicking behavior leads to increased behavior similarity and to markets gravitating toward a state of equilibrium. Another example consistent with the equilibration perspective is Meyer, Brooks, and Goes (1990, 98) during the period of "The 1960s: Evolution Via Institutional Isomorphism." In their historical analysis of the San Francisco Bay area hospital industry, the authors found that during the 1960s this industry was characterized by incremental, or continuous, change resulting in the homogenization of the industry. Other works that fall within the equilibration perspective include Shane (Shane 2000, 2012), Shane and Venkataraman (2000), Dew, Velamuri, and Venkataraman (2004), McMullen and Shepherd (2006), Kor, Mahoney, and Michael (2007), Loasby (2007), Harper and Endres (2010), and Valliere (2013).

\section{Punctuated Equilibrium}

Schumpeter, with his notion of creative destruction, is the key economist taking a punctuated equilibrium perspective. Creative destruction refers to a dynamic process in which new entrants 
introduce superior new technologies to the market, making existing technologies obsolete and forcing incumbents to exit the market (Pe'er and Vertinsky 2008). The monopolistic profits that new entrants may realize serve as an incentive for innovation, attracting more players to the market; in turn, this results in economic rents eventually being competed away and in the market returning to equilibrium until another innovation occurs (Packard and Bylund 2018; Schumpeter 1934). This process comprises two distinctive features. First, innovation results in markets shifting through brief and violent upheavals from one equilibrium state to another (Chiles, Vultee, et al. 2010), suggesting the occurrence of discontinuous change. Second, a new wave of entrepreneurs is able to enter the market and compete rents away, implying that innovative technology and knowledge are ultimately shared and coordinated through the market process (McMullen and Shepherd 2006). For these reasons, the punctuated equilibrium perspective is characterized by discontinuous change and convergent knowledge. Importantly, this is a theoretical construction; in practice, Schumpeterian shocks spread to the market through the production process and could take a relatively long time to do so. Before the shock, the market tends toward equilibrium and is approaching a WSR; when the shock arrives, it profoundly modifies the capital structure (i.e., capital and prices will be reallocated and readjusted as in Lachmann 1976; Rothbard [1962, 1970] 2009) and the formerly existing foreseeable WSR gives way to a completely different WSR. As such, the shock diverts the WSR somewhere very different from where it was thought to be going before. Although not using the terms equilibration and punctuated equilibrium, previous work has demonstrated that in real-world markets both perspectives are necessary to economic development and that they tend to coexist (e.g., D'Andrea and Mazzoni 2019; Packard and Bylund 2018). This helps explain why in this typology some entrepreneurship work appears in both the equilibration and punctuated equilibrium perspectives.

Organizational research conducted within this perspective is often rooted in a critical realist paradigm. Critical realists believe that there is a world that exists independently of human consciousness, with knowledge about this world of events being socially constructed (Denzin and Lincoln 2005). Furthermore, critical realists are interested in not only explaining but also 
changing the world. To that end, they seek to identify, reflect on, and change the structures underlying human action (Alvesson and Sköldberg 2009). In regard to entrepreneurship, this means that the entrepreneur can actively respond to and shape the world (Chiles, Vultee, et al. 2010)—a perspective that is characterized by a realist ontology grounded in a "real" reality that one can only apprehend in an imperfect and probabilistic manner (Chiles, Vultee, et al. 2010; Guba and Lincoln 2005). Additionally, this paradigm is typified by a modified dualist/objectivist epistemology in which findings are considered to be probably true (Guba and Lincoln 2005) and by a mostly quantitative/statistical/variance methodology, although it may include some qualitative methods (Chiles, Vultee, et al. 2010; Guba and Lincoln 2005). Although the critical realist paradigm appears to be similar to the postpositivist paradigm, it is important to note that the latter is characterized as more objectivist than the former (Chiles, Vultee, et al. 2010).

Anderson and Tushman's (1990) longitudinal study of the U.S. cement, glass, and minicomputer industries is consistent with the perspective of punctuated equilibrium. Not only do the authors mention Schumpeter in their opening paragraph, they also frame their study in a way that is consistent with Schumpeter's view of change. Particularly, the authors "empirically explore when and how dominant designs emerge from technological discontinuities" (Anderson and Tushman 1990, 604) to illustrate that technological discontinuities, or disrupting innovations, trigger periods of upheaval that are followed by a period of order, which in turn is disrupted by a new technological discontinuity. Another empirical example is Meyer, Brooks, and Goes's $(1990,101)$ discussion of the period of "The 1980s: Industry Revolution." In their historical analysis of the San Francisco Bay area hospital industry, the authors found that, during the 1980s, this industry was characterized by discontinuous changes leading to restructuration, reconstitution, and adaptation. Lastly, other entrepreneurship works that fall within the punctuated equilibrium perspective include Guth and Ginsberg (1990), Shane (1996, 2012), Shane and Venkataraman (2000), Dew, Velamuri, and Venkataraman (2004), Venkataraman (2004), McMullen and Shepherd (2006), Kor, Mahoney, and Michael (2007), Loasby (2007), and Valliere (2013). 


\section{Disequilibration and Punctuated Disequilibrium}

Lachmann and Shackle are the key economists of disequilibration and punctuated disequilibrium, respectively. Their assumptions are similar in that their view of the world is rooted in the same paradigm. For this reason, they are often grouped under the "Lachmann-Shackle position." As Walter E. Grinder $(1977,20)$ explains,

The Lachmann-Shackle position that forces of divergence tend to outweigh forces of convergence makes a general market equilibrium unlikely. According to Lachmann, the strength of the forces of convergence depends almost entirely on the activities of entrepreneurs. If entrepreneurs take advantage of the price-cost discrepancies attending changing circumstances, the entrepreneurial function of using resources in search of profit (the process of innovation and imitation) will, as most Austrian economists agree, lead to a convergence of the plans of individuals in markets. However, because change is ever present and unpredictable, individuals have different expectations about the character and extent of change. It is this factor more than any other that precludes anything approaching a macroeconomic general equilibrium in the uncertain world of market activity.

The Lachmann-Shackle position is rooted in radical subjectivism-an approach that recognizes entrepreneurs' divergent interpretations of complex phenomena and, thus, their divergent knowledge. In this disequilibrium-based approach, divergent knowledge eventually results in increasingly heterogeneous markets as entrepreneurs' plans and actions collide, forcing them to revise and change their subjective future expectations and knowledge (Chiles, Vultee, et al. 2010). Although Lachmann and Shackle have a similar take on knowledge divergence, they do differ in their approach to change. In disequilibration, change in the market process has a continuous nature. For instance, Lachmann is known for advocating disequilibrium processes in a world of continuous change and reorganization (Harper and Endres 2010; Lachmann 1956). ${ }^{5}$ In punctuated disequilibrium, market

${ }^{5}$ Lachmann acknowledged the operation of both equilibrating and disequilibrating forces in market processes (see, e.g., Lachmann 1986). His early work in capital theory gave the distinct impression that equilibrating forces dominated (Barbieri 2017; Lewin 1997), while his later work, which was more radically subjective, emphasized or at least logically implied the dominance of disequilibrating forces 
processes change in a kaleidic manner; that is, markets shift, or change, abruptly from one disequilibrium phase to another (Chiles, Vultee, et al. 2010; Shackle 1967). Thus, while the disequilibration perspective involves continuous change and divergent knowledge, the punctuated disequilibrium perspective entails discontinuous change and divergent knowledge. Furthermore, in both disequilibration and punctuated disequilibrium entrepreneurial actions drive the market away from the WSR; however, in punctuated disequilibrium this process occurs in abrupt punctuations. Reminiscent of Schumpeterian shocks, an action or event, or a set of actions and events, abruptly punctuates the disequilibrium market, kaleidically shifting it from one disequilibrium phase to another.

Organizational research conducted within the disequilibration and punctuated disequilibrium perspectives is often grounded in a social constructivist/interpretivist view of the world-i.e., they are both rooted in the same paradigm. In this paradigm, researchers search for an understanding of the world surrounding them by gathering subjective and intersubjective meanings of experience (Creswell 2007; Morgan 1980). Such meanings are thus complex, multiple, and varied (Creswell 2007). Indeed, researchers may even find that different individuals will have different perspectives of phenomena, leading to evidence of multiple realities (Creswell 2007; Morgan 1980). The term social constructivism refers to the idea that meanings are formed by interacting with others (Creswell 2007). In practice, social constructivist/interpretivist researchers ask general and broad questions that lead participants to build the meaning of phenomena through discussions or interactions with others. This allows researchers to address ongoing and dynamic processes of social interaction while focusing on context to understand the cultural and historical settings of participants and

(Barbieri 2017; Boehm et al. 2000; Chiles, Vultee, et al., 2010; Lewin 2001, 2007). Barbieri (2017) dubs this evolution of Lachmann's thought Lachmann I and Lachmann II, respectively. Our placement of, and emphasis on, Lachmann in the disequilibration quadrant of the proposed typology accords with Lachmann II. Although organizational entrepreneurship scholars pursuing Austrian radical subjectivism have embraced this Lachmann II interpretation (Chiles, Vultee, et al., 2010), they have also observed in Lachmann's later work "a two-stage process, in which early market equilibration, attributable to close imitation of innovators' products, eventually yields to market disequilibration, attributable to secondary innovations that differentiate rivals' products" (Chiles, Vultee, et al., 2010, 159). 
phenomena (Creswell 2007). Additionally, social constructivists / interpretivists recognize that their own historical, personal, and cultural experiences shape their interpretations. Thus, the goal of these researchers is to make sense of, or interpret, the meanings the world has to different individuals based on their own backgrounds (Creswell 2007; Morgan 1980). This is why social constructivism and interpretivism are often combined (Creswell 2007).

Entrepreneurship research based on a social constructivist/interpretivist paradigm is characterized by a relativist ontology (Chiles, Vultee, et al. 2010), referring to "local and specific co-constructed realities" (Guba and Lincoln 2005, 195); a transactional/ subjectivist epistemology, meaning that findings are co-created; and a process / hermeneutical/dialectical methodology (Chiles, Vultee, et al. 2010; Guba and Lincoln 2005). Scholars taking a social constructivist/ interpretivist approach attempt to preserve the interpretations of those under study as well as their own, even if they are different or contradictory. This may lead to different perspectives, or multiple realities, which paves the way for a holistic understanding of the phenomenon under study (Stake 1995).

A research example that is consistent with the disequilibration perspective of Austrian economics is Hambrick et al. (2005). In their empirical study of the U.S. steel industry, the authors challenge the traditional view of institutional theory as argued by DiMaggio and Powell (1983) by suggesting that organizations do not become increasingly similar over time due to isomorphic pressures. Rather, they become less similar due to several macrosocial trends that the original authors did not anticipate (Hambrick et al. 2005). The way these authors frame their study is consistent with a disequilibration perspective, in which continuous change throughout time results in knowledge divergence and, consequently, a movement away from the WSR. Moreover, diversity is an indicator of disequilibrium (e.g., Kirzner 1973); thus, increasing diversity is an indicator of disequilibration. Another empirical example taking a disequilibration perspective is Meyer, Brooks, and Goes's (1990, 100) discussion of the period of "The 1970s: Organizational Adaptation." In their historical analysis of the San Francisco Bay area hospital industry, the authors found that during that period this industry was primarily characterized by incremental change and adaptation in different directions, leading to increasing interorganizational 
diversity. Lastly, other work in entrepreneurship that falls within the disequilibration perspective of the typology includes Dew, Velamuri, and Venkataraman (2004), Greenwood and Suddaby (2006), Chiles, Bluedorn, and Gupta (2007), Loasby (2007), Foss and Ishikawa (2007), Kor, Mahoney, and Michael (2007), Chiles, Tuggle, et al. (2010), Harper and Endres (2010), Mathews (2010), and Dolmans et al. (2014).

Chiles, Meyer, and Hench (2004) is an example of research that is consistent with the punctuated disequilibrium perspective. Their study of the musical theaters of Branson, Missouri, found that new organizational collectives evolve in a perpetual state of disequilibrium through an extended series of punctuation events, each of which ushers in a new disequilibrium phase qualitatively different from the one before. Such findings, the authors argued, "support a 'punctuated disequilibrium' view of change" (514, emphasis in original). Another empirical example of the same perspective is Chiles, Vultee, et al. (2010). Analyzing the Japanese beer industry, the authors concluded that this industry is characterized by disequilibrium market processes, continual disruption, and increasing heterogeneity. The authors' analysis also provides an illustration of one methodological approach (hermeneutics; see Lachmann 1991) that can be used to study entrepreneurial phenomena from a radical subjectivist perspective. Lastly, other work in entrepreneurship that falls within the punctuated disequilibrium perspective of the typology include Chiles, Tuggle, et al. (2010) and Chiles et al. (2013).

\section{FUTURE RESEARCH USING THE TYPOLOGY}

Keeping in mind the broad philosophical assumptions relating to each of the typology's perspectives, let us now take a closer look at the different accounts of the nature of the entrepreneur and the nature of opportunities by themajor Austrianeconomists withineach perspective (see figure 3 for a summary). An overview of these is provided next as a basis for developing possible research questions (shown in figure 4) that scholars may find of interest in future research and that are appropriate for each perspective. Because this work is building on the work of Chiles, Vultee, et al. (2010), some of the research questions developed by these authors have been included intentionally, appropriately placed and organized within the typology's four perspectives. 


\section{Figure 3. A Typology of Four Austrian Perspectives for Entrepreneurship Research: The Nature of the Entrepreneur and Opportunities}

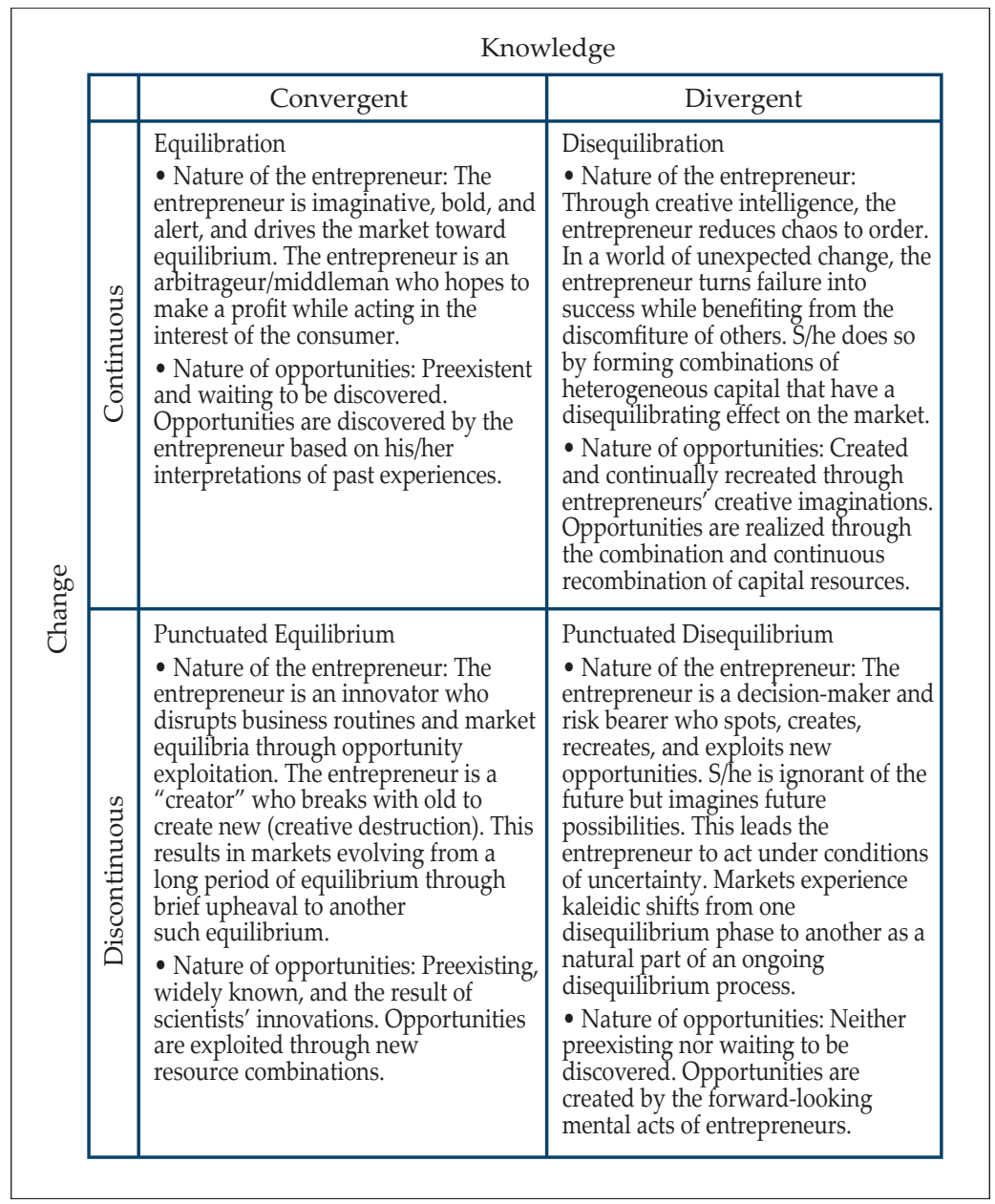




\section{Figure 4. A Typology of Four Austrian Perspectives for Entrepreneurship Research: Potential Research Questions}

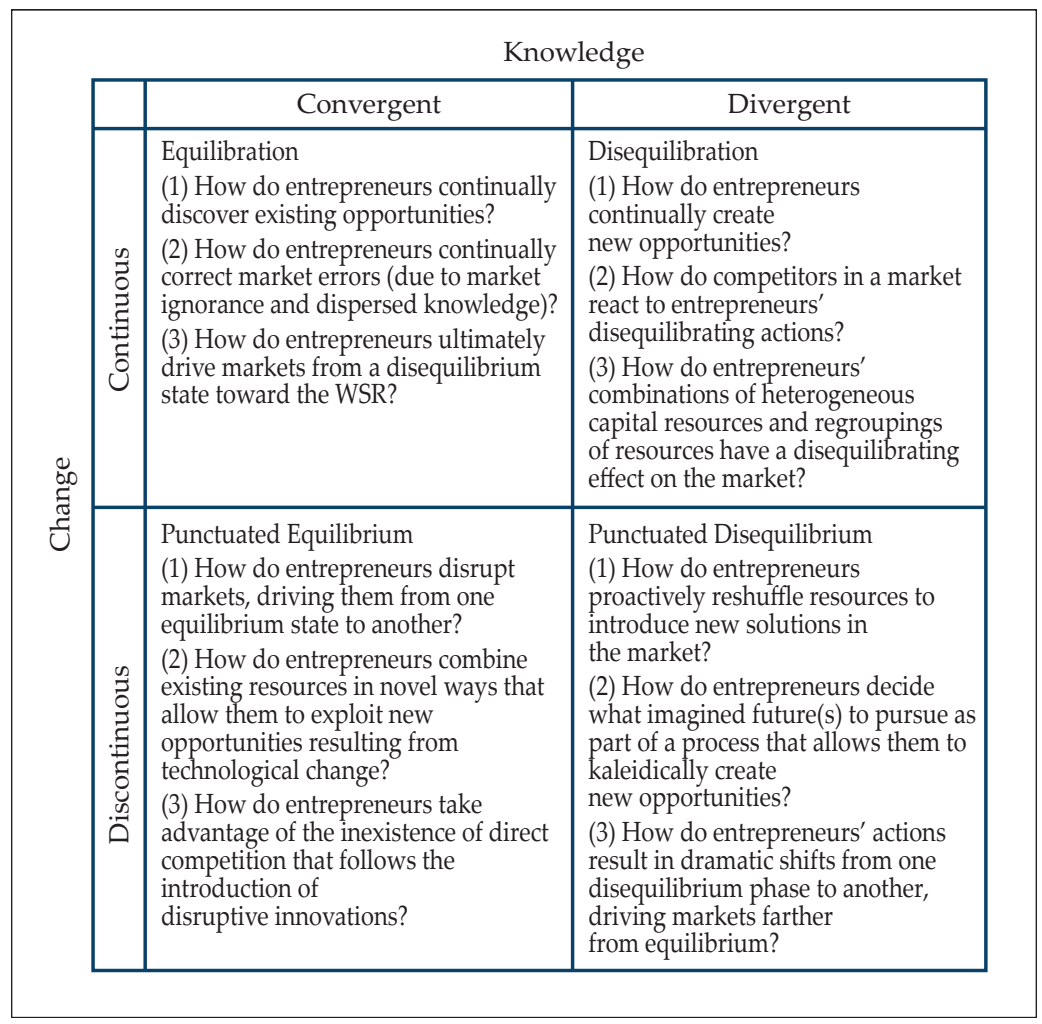

\section{Equilibration}

Scholars taking an equilibration perspective view the entrepreneur as an imaginative and bold individual who is alert to opportunities (Kirzner 1997). By discovering and taking advantage of opportunities, the entrepreneur drives the market toward equilibrium, reducing Hayekian problems of dispersed knowledge through the coordination of diverse plans (Jakee and Spong 2003). In this perspective, as time passes, the WSR nears and nears in the various markets. Scholars using an equilibration perspective view 
the entrepreneur as an arbitrageur/middleman who buys or sells hoping to make a profit; thus $\mathrm{s} /$ he is someone who need not be a producer or an innovator, or even own capital (Foss and Klein 2010; Rothbard [1962, 1970] 2009). Lastly, the entrepreneur is an agent of change who profits by taking advantage of opportunities while acting in the interest of the consumer (Mises [1949] 1998). Austrian economists within the equilibration perspective view opportunities as preexistent in the market and as waiting to be discovered. Entrepreneurs discover such opportunities based on their own interpretations of past experiences (see Chiles, Vultee, et al. 2010).

Taking into consideration the aforementioned assumptions and information regarding the nature of change, knowledge, opportunities, and the entrepreneur, scholars wishing to pursue research using an equilibration perspective may consider asking questions such as (1) How do entrepreneurs continually discover existing opportunities?, (2) How do entrepreneurs continually correct market errors (due to market ignorance and dispersed knowledge)?, and (3) How do entrepreneurs ultimately drive markets from a disequilibrium state toward the WSR?

\section{Punctuated Equilibrium}

Proponents of this perspective view the entrepreneur as an innovator who disrupts business routines and market equilibria through opportunity exploitation (Jakee and Spong 2003). As such, the entrepreneur is not passive- $\mathrm{s} /$ he creates a world that is different from the one $\mathrm{s} /$ he finds-meaning that the entrepreneur is, in fact, a "creator" (Foss and Klein 2020; Kirzner 2009). However, it is important to note that although the entrepreneur is a creator and an innovator, $\mathrm{s} /$ he does not necessarily need to be an inventor or a capitalist (Schumpeter 1934). Additionally, the entrepreneur is different from a manager in that while managers perform routine activities, entrepreneurs rely less on tradition. In fact, entrepreneurs break with the old to create something new-a process known as creative destruction (Schumpeter 1934). Entrepreneurs exploit preexisting opportunities that are widely known and that are a result of scientists' inventions (Chiles, Vultee, et al. 2010). In order to exploit such opportunities, entrepreneurs periodically carry out new resource combinations through their will and action (Bylund 
2016; Foss and Klein 2012; Schumpeter 1934). This results in markets evolving "from one long period of equilibrium through brief upheaval to another such equilibrium" (Chiles, Vultee, et al. 2010, 140). From an Austrian equilibrium perspective, such entrepreneurial actions interrupt the path toward a WSR, thus suggesting a different, much more distant WSR toward which markets will tend once the rearrangement of production processes starts.

Taking into consideration the aforementioned assumptions and information regarding the nature of change, knowledge, opportunities, and the entrepreneur, scholars wishing to pursue research using a punctuated equilibrium perspective may consider asking questions such as (1) How do entrepreneurs disrupt markets, driving them from one equilibrium state to another?, (2) How do entrepreneurs combine existing resources in novel ways that allow them to exploit new opportunities resulting from technological change?, and (3) How do entrepreneurs take advantage of the inexistence of direct competition that follows the introduction of disruptive innovations?

\section{Disequilibration}

Scholars taking a disequilibration perspective view entrepreneurs as capable of reducing chaos to order through their creative intelligence (Harper and Endres 2010). In a world of continuous change, entrepreneurs act because they "prefer to anticipate tomorrow's changes today rather than adjust themselves to those recorded in the latest message received" (Lachmann 1956, 22). They do so by forming combinations of heterogeneous capital resources in their plans and regrouping resources when their plans are revised, a process that ultimately has a disequilibrating effect on the market. Overall, the function of the entrepreneur is to address a world of unexpected change, as well as "to turn failure into success and to benefit from the discomfiture of others" (Lachmann 1956, 18). Opportunities are created and continually recreated through entrepreneurs' creative imaginations, and they are realized through the combination and continuous recombination of capital resources (Chiles et al. 2013). Entrepreneurs' actions cause markets to move away from the previously seen WSR step by step, thus reducing market order. 
Taking into consideration all of the aforementioned assumptions and information regarding the nature of change, knowledge, opportunities, and the entrepreneur, scholars wishing to pursue research using a disequilibration perspective may consider asking questions such as (1) How do entrepreneurs continually create new opportunities?, (2) How do competitors in a market react to entrepreneurs' disequilibrating actions?, and (3) How do entrepreneurs' combinations of heterogeneous capital resources and regroupings of resources have a disequilibrating effect on the market?

\section{Punctuated Disequilibrium}

Under a punctuated disequilibrium perspective, the entrepreneur spots, creates, and exploits new opportunities. S/he is a decision-maker and a risk bearer under conditions of uncertainty (Batstone and Pheby 1996). And although the entrepreneur is ignorant of the future (Hill 2004), s/he possesses an imaginative capacity to ponder future possibilities (Ripsas 1998). Based on subjective expectations of imagined future possibilities, entrepreneurs make decisions that allow them to continually create and recreate opportunities (Chiles, Vultee, et al. 2010). Thus, opportunities are neither preexisting nor waiting to be discovered-they are created by the forward-looking mental acts of entrepreneurs (Chiles, Vultee, et al. 2010; Shackle 1979). Envisioning different courses of action leads to a divergence of expectations and, thus, to a kaleidic society - a notion that is vastly different from Hayek's self-adjusting spontaneous order (Hill 2004). Ultimately, this results in a punctuated disequilibrium in which markets occasionally experience dramatic shifts from one disequilibrium phase to another as a natural part of an ongoing disequilibrium process (Chiles, Vultee, et al. 2010). In this perspective, such dramatic punctuations drive the market away from the WSR, kaleidically shifting it from one disequilibrium phase to another and allowing the entrepreneur responsible for that shift to collect quasi-monopolistic profits for as long as the situation remains.

Taking into consideration the aforementioned assumptions and information regarding the nature of change, knowledge, opportunities, and the entrepreneur, scholars wishing to pursue research using a punctuated disequilibrium perspective may consider asking 
questions such as (1) How do entrepreneurs proactively reshuffle resources to introduce new solutions in the market?, (2) How do entrepreneurs decide what imagined future(s) to pursue as part of a process that allows them to kaleidically create new opportunities?, and (3) How do entrepreneurs' actions result in dramatic shifts from one disequilibrium phase to another, driving markets farther from equilibrium?

\section{CONCLUDING THOUGHTS}

Austrian economists bring an important perspective on the history of economic thought, one that views the world as inherently cognitive and fundamentally dynamic; that is, about knowledge and change- -knowledge that is both convergent and divergent, and change that is both continuous and discontinuous. By placing these concepts at the core of their enterprise, these economists have shed considerable light on the "dark forces of time and ignorance." In acknowledging the concept of equilibrium in the Austrian tradition and building a typology based on the aforementioned two concepts, which are intricately connected to the Austrian concept of entrepreneurial production, the hope is to offer organizational entrepreneurship scholars a useful framework for organizing their thinking and guiding their research — not only into the more familiar equilibrium-based entrepreneurial phenomena, but also the less familiar disequilibrium ones.

As has been argued, Austrian economics comprises a number of distinct strands or perspectives, each with a unique ability to shed light on specific entrepreneurial phenomena. This work seeks to sensitize organizational scholars pursuing Austrian-inspired entrepreneurship research to the intellectual heterogeneity within this school of economic thought and to clarify the nuances of different perspectives within it, providing scholars with a solid foundation from which to build their research efforts. To do so, ideas from existing typologies in the organization studies literature were integrated and reworked to develop a new typology yielding four distinct perspectives: (1) equilibration, (2) punctuated equilibrium, (3) disequilibration, and (4) punctuated disequilibrium. The equilibration and punctuated equilibrium perspectives, which have garnered the lion's share of scholarly attention, are firmly anchored in 
a perceived tendency for market actions to be directed toward some equilibrium, represented in Austrian theorizing by the WSR and the tendency toward the ERE. These perspectives have been valuable in moving the organizational entrepreneurship field forward for the last several decades. However, scholars have leaned on them heavily, and this overreliance has blocked progress into a range of disequilibrium phenomena, from entrepreneurs' forward-looking imaginative acts to their ex nihilo creation and continual recreation of resource combinations to the relatively unstable interactions these acts and actions engender in markets characterized by radical uncertainty, pervasive heterogeneity, and constant disruption. The disequilibration perspective, in which entrepreneurial action drives the market process away from equilibration, has recently started to receive greater attention, opening inquiry into some of these neglected entrepreneurial phenomena. Its place in this typology further legitimates it as an important perspective in entrepreneurship research. The punctuated disequilibrium perspective is just beginning to appear on scholars' radars and it is hoped that its place in this typology will compel others to explore some of the current "outer reaches" of the entrepreneurship field, helping us understand, for example, how creative entrepreneurial processes kaleidically shift from one disequilibrium phase to another.

More generally, organizational entrepreneurship scholars can use this typology to better understand how different Austrian perspectives are rooted in distinct sets of philosophical and methodological assumptions. Using this typology, scholars can also locate key differences over the nature of the entrepreneur, the nature of opportunities, potential research questions, and selected empirical examples that illustrate the types of phenomena with which each perspective is concerned. Additionally, for each of its four perspectives this typology lists authors whose work can serve as a reference point. This typology is useful and important because it provides organizational entrepreneurship scholars with a foundation to advance inquiry in at least two ways: (1) it helps scholars organize and sharpen their thinking about a particular entrepreneurial phenomenon, and (2) it guides researchers through the research process, allowing them to identify and make sense of the nuances and subtleties of the phenomenon under study, to ask appropriate questions, and to use suitable methodologies. 
Scholars pursuing Austrian-based organizational entrepreneurship research might use this typology in the following manner. First, it is recommended that scholars start by reflecting on the nature of the phenomena they wish to study, specifically seeking an understanding of the nature of knowledge, change, opportunities, and of the entrepreneur (see figures 2 and 3). This will allow them to locate the phenomenon at hand within a particular Austrian perspective. As soon as researchers identify the appropriate perspective, they should examine and reflect upon the broader philosophical assumptions relating to the particular perspective (see figure 2). After that, they can develop research questions that are consistent with the perspective and its underlying philosophical assumptions (see figure 4 for examples). Finally, researchers can choose the appropriate methodology, which should also be consistent with the philosophical assumptions of the perspective being used (see figure 2 ). In the case that the researcher would like to consult previous work using a specific perspective, figure 2 offers lists of works that fall within each perspective.

Although helpful for sharpening our thinking about the numerous strands of Austrian and Austrian-related economics, this typology is not without limitations. First, some scholars criticize typologies for not being a true depiction of reality - that is, for being oversimplistic and for failing to portray the complexity of organizational life (Meyer, Tsui, and Hinings 1993). It is important to keep in mind, however, that the purpose of typologies is not to perfectly replicate reality but rather to provide a foundation from which to advance inquiry. As Gibson Burrell and Gareth Morgan (1979) have argued, typologies are useful in providing us with a heuristic device, rather than with a set of rigid definitions and classifications. In other words, typologies are designed to help sharpen our conceptions and thoughts about the dynamism of reality without getting lost in an absolutism that is not real. Thus, typologies provide scholars with constructs that help organize their thinking, from which they can then identify the nuances and subtleties that differentiate real phenomena from the ideal types. Given the process orientation of the Austrian school, this typology might be of particular interest to those interested in exploring entrepreneurship from a process perspective. It is recommended that future process-oriented scholars use this typology alongside other work exploring distinct 
worldviews in entrepreneurship scholarship-see, for example, the work of Chiles, Sara R. S. T. A. Elias, and Qian Li (2017)—to carefully consider the philosophical assumptions that undergird their research efforts.

Second, in developing this typology, and as is typical of this type of work, the two dimensions of knowledge and change were classified dichotomously, even though these are complex and nonbinary concepts. This approach thus prioritized parsimony, glossing over the complexity and nuances of these concepts (Doty and Glick 1994; Weick 1979). As Peer C. Fiss $(2007,1193)$ has argued, many concepts in the field are complex and multidimensional in nature, "requiring more continuous coding." Future researchers are thus encouraged to explore alternative approaches, for example, by using qualitative comparative analysis (QCA) to develop an "ideal type" (e.g., Fiss 2011) for each key Austrian economist and their impact on organization and entrepreneurship studies.

Third, the two dimensions of knowledge and change provide one way to make sense of the various strands of Austrian and Austrian-related economics. Future scholars might build different typologies by choosing dimensions that may be rooted not only in other Austrian core concepts, but also in key differences between the Austrian school and mainstream economic thought (e.g., methodological individualism, subjectivism, praxeology). Developing new typologies would inherently allow future scholars to shed different light on-and further make sense of-the complexities of Austrian thought more specifically and economic thought more generally, and how the former may inspire organizational research.

Fourth, it is recognized that there are a number of important debates within the Austrian school that were not included in this discussion, such as Mises versus Hayek on the economic problem arising from power centralization (Salerno 1993), Mises versus Schumpeter on the theoretical grounds of economics (Schulak and Unterköfler 2011), and Kirzner versus Rothbard on the nature of the entrepreneur (Rothbard 1974). This typology represents a first step in helping guide the research efforts of organizational entrepreneurship scholars wishing to more firmly ground their research in Austrian thought. As such, it is a basic conceptual tool for holistically making sense of Austrian economics, allowing 
organizational entrepreneurship scholars to go beyond mere lists of go-to Austrian figures such as Hayek, Schumpeter, and Kirzner. The aforementioned debates provide theoretical detail and nuance that go beyond the initial efforts in this article. Future scholars are encouraged to flesh out this ty pology by adding the relevant insights from these debates to the appropriate perspective or, conversely, to explore how this typology might inform these debates.

In closing, the hope is that this typology, along with these concluding suggestions, will help organizational scholars pursue Austrian-based entrepreneurship research in a more mindful and informed manner. Doing so will improve our understanding of entrepreneurship.

\section{REFERENCES}

Alvesson, Mats, and Kaj Sköldberg. 2009. Reflexive Methodology: New Vistas for Qualitative Research. 2d ed. London: Sage Publications.

Anderson, Philip, and Michael L. Tushman. 1990. “Technological Discontinuities and Dominant Designs: A Cyclical Model of Technological Change." Administrative Science Quarterly 35, no. 4: 604-33. https://doi. org/10.2307/2393511.

Asaba, Shigeru, and Marvin B. Lieberman. 1999. "Why Do Firms Behave Similarly? A Study on New Product Introductions in the Japanese Soft-Drink Industry." Academy of Management Proceedings. https://doi. org/10.5465/apbpp.1999.27594817.

Barbieri, Fabio. 2017. "Lachmann's Transformation." Paper presented at The Legacy of Ludwig Lachmann: Interdisciplinary Perspectives on Institutions, Agency and Uncertainty Conference, Johannesburg, South Africa.

Batstone, Stephen, and John Pheby. 1996. "Entrepreneurship and Decision Making: The Contribution of G.L.S. Shackle." International Journal of Entrepreneurial Behavior and Research 2, no. 2: 34-51. https://doi. org/10.1108/13552559610119322.

Boehm, Stephan, Israel M. Kirzner, Roger Koppl, Don Lavoie, Peter Lewin, and Christopher Torr. 2000. "Professor Ludwig M. Lachmann (19061990): Scholar, Teacher, and Austrian School Critic of Late Classical Formalism in Economics." American Journal of Economics and Sociology 59, no. 3: 367-417. https://doi.org/10.1111/1536-7150.00034. 
Burrell, Gibson, and Gareth Morgan. 1979. Sociological Paradigms and Organizational Analysis: Elements of the Sociology of Corporate Life. Portsmouth, NH: Heinemann Educational Books.

Bylund, Per L. 2016. The Problem of Production: A New Theory of the Firm. Abingdon, U.K.: Routledge.

—_ 2019. "The Austrian Free Enterprise Ethic: A Mengerian Comment on Kirzner." Review of Austrian Economics. https://doi.org/10.1007/ s11138-019-00496-3.

Cheah, Hock-Beng. 1990. "Schumpeterian and Austrian Entrepreneurship: Unity within Duality." Journal of Business Venturing 5, no. 6: 341-47. https://doi.org/10.1016/0883-90269090010-Q.

Chiles, Todd H., Allen C. Bluedorn, and Vishal K. Gupta. 2007. “Beyond Creative Destruction and Entrepreneurial Discovery: A Radical Austrian Approach to Entrepreneurship." Organization Studies 28, no. 4: 467-93. https://doi.org/10.1177/0170840606067996.

Chiles, Todd H., Sara R. S. T. A. Elias, and Qian Li. 2017. "Entrepreneurship as Process." Pp. 432-50 in The SAGE Handbook of Process Organization Studies, ed. Ann Langley and Haridimos Tsoukas. London: Sage Publications.

Chiles, Todd H., Sara R. S. T. A. Elias, Tal G. Zarankin, and Denise M. Vultee. 2013. "The Kaleidic World of Entrepreneurs: Developing and Grounding a Metaphor for Creative Imagination." Qualitative Research in Organizations and Management 8, no. 3: 276-307. https://doi. org/10.1108/QROM-05-2012-1070.

Chiles, Todd H., Alan D. Meyer, and Thomas J. Hench. 2004. "Organizational Emergence: The Origin and Transformation of Branson, Missouri's Musical Theaters." Organization Science 15, no. 5: 499-519. https://doi.org/10.1287/orsc.1040.0095.

Chiles, Todd H., Christopher S. Tuggle, Jeffery S. McMullen, Leonard Bierman, and Daniel W. Greening. 2010. “Dynamic Creation: Extending the Radical Austrian Approach to Entrepreneurship." Organization Studies 31, no. 1: 7-46. https://doi.org/10.1177/0170840609346923.

Chiles, Todd H., Denise M. Vultee, Vishal K. Gupta, Daniel W. Greening, and Christopher S. Tuggle. 2010. "The Philosophical Foundations of a Radical Austrian Approach to Entrepreneurship." Journal of Management Inquiry 19, no. 2: 138-64. https://doi. org/10.1177/1056492609337833. 
Creswell, John W. 2007. Qualitative Inquiry and Research Design: Choosing among Five Traditions. 2d ed. Thousand Oaks, Calif.: Sage Publications.

Cunliffe, Ann L. 2011. “Crafting Qualitative Research: Morgan and Smircich 30 Years On." Organizational Research Methods 14, no. 4: 647-73. https:// doi.org/10.1177/1094428110373658.

D’Andrea, Fernando, and João Fernando Mazzoni. 2019. "For a Less Dramatic Creative Destruction: Innovation and Entrepreneurship as Features of the Market Process." MISES 7, no. 3. https://doi. org/10.30800/mises.2019.v7.1245.

Dean, Thomas J., and G. Dale Meyer. 1996. "Industry Environments and New Venture Formations in U.S. Manufacturing: A Conceptual and Empirical Analysis of Demand Determinants." Journal of Business Venturing 11, no. 2: 107-32. https://doi.org/10.1016/0883-90269500109-3.

Denzin, Norman K., and Yvonna S. Lincoln. 2005. "Introduction: The Discipline and Practice of Qualitative Research." Pp. 1-32 in The SAGE Handbook of Qualitative Research, ed. Norman K. Denzin and Yvonna S. Lincoln. 3d ed. Thousand Oaks, Calif.: Sage Publications.

Dew, Nicholas, S. Ramakrishna Velamuri, and Sankaran Venkataraman. 2004. "Dispersed Knowledge and an Entrepreneurial Theory of the Firm." Journal of Business Venturing 19, no. 5: 659-79. https://doi. org/10.1016/j.jbusvent.2003.09.004.

DiMaggio, Paul J., and Walter W. Powell. 1983. “The Iron Cage Revisited: Institutional Isomorphism and Collective Rationality in Organizational Fields." American Sociological Review 48, no. 2: 147-60. https:// doi.org/10.2307/2095101.

Dolmans, Sharon A. M., Elco van Burg, Isabelle M. M. J. Reymen, and A. Georges L. Romme. 2014. "Dynamics of Resource Slack and Constraints: Resource Positions in Action." Organization Studies 35, no. 4: 511-49. https://doi.org/10.1177/0170840613517598.

Doty, D. Harold, and William H. Glick. 1994. “Typologies as a Unique Form of Theory Building: Toward Improved Understanding and Modeling." Academy of Management Review 19, no. 2: 230-51. https:// doi.org/10.5465/amr.1994.9410210748.

Ekelund, Robert B., and Robert F. Hébert. 2014. A History of Economic Theory and Method. 6th ed. Long Grove, Ill.: Waveland Press, Inc. 
Fiss, Peer C. 2007. "A Set-Theoretic Approach to Organizational Configurations." Academy of Management Review 32, no. 4: 1180-98. https://doi. org/10.5465/amr.2007.26586092.

—_ 2011. “Building Better Causal Theories: A Fuzzy Set Approach to Typologies in Organization Research." Academy of Management Journal 54, no. 2: 393-420. https://doi.org/10.5465/amj.2011.60263120.

Foss, Nicolai J., and Ibuki Ishikawa. 2007. "Towards a Dynamic Resource-based View: Insights from Austrian Capital and Entrepreneurship Theory." Organization Studies 28, no. 5: 749-72. https://doi. org/10.1177/0170840607072546.

Foss, Nicolai J., and Peter G. Klein. 2010. “Entrepreneurial Alertness and Opportunity Discovery: Origins, Attributes, Critique." Pp. 98-120 in Historical Foundations of Entrepreneurship Research, ed. Hans Landström and Franz Lohrke. Cheltenham, U.K.: Edward Elgar.

- 2012. Organizing Entrepreneurial Judgment: A New Approach to the Firm. New York: Cambridge University Press.

— 2020. "Entrepreneurial Opportunities: Who Needs Them?" Academy of Management Perspectives 34, no. 3. https://doi.org/10.5465/amp.2017.0181.

Gloria-Palermo, Sandye. 1999. The Evolution of Austrian Economics: From Menger to Lachmann. London: Routledge.

Gourlay, Stephen. 2006. “Towards Conceptual Clarity for 'Tacit Knowledge': A Review of Empirical Studies." Knowledge Management Research and Practice 4, no. 1: 60-69. https://doi.org/10.1057/palgrave.kmrp.8500082.

Greenwood, Royston, and Roy Suddaby. 2006. "Institutional Entrepreneurship in Mature Fields: The Big Five Accounting Firms." Academy of Management Journal 49, no. 1: 27-48. https://doi.org/10.5465/ AMJ.2006.20785498.

Grinder, Walter E. 1977. "In Pursuit of the Subjective Paradigm." Pp. 3-24 in Capital, Expectations, and the Market Process: Essays on the Theory of the Market Economy. Kansas City, Kans.: Sheed Andrews and McMeel, Inc.

Guba, Egon G., and Yvonna S. Lincoln. 2005. “Paradigmatic Controversies, Contradictions, and Emerging Confluences." Pp. 191-215 in The SAGE Handbook of Qualitative Research, ed. Norman K. Denzin and Yvonna S. Lincoln. 3d ed. Thousand Oaks, Calif.: Sage Publications. 
Guth, William D., and Ari Ginsberg. 1990. “Guest Editors' Introduction: Corporate Entrepreneurship." Strategic Management Journal 11: 5-15. https://www.jstor.org/stable/2486666.

Hambrick, Donald C., Sydney Finkelstein, Theresa S. Cho, and Eric M. Jackson. 2005. "Isomorphism in Reverse: Institutional Theory as an Explanation for Recent Increases in Intraindustry Heterogeneity and Managerial Discretion." Research in Organizational Behavior 26: 307-50. https://doi.org/10.1016/S0191-3085(04)26008-7.

Harcourt, G. C. 1981. "Notes on an Economic Querist: G.L.S. Shackle." Journal of Post Keynesian Economics 4, no. 1: 136-44. https://doi.org/10.1 080/01603477.1981.11489268.

Harper, David A., and Anthony M. Endres. 2010. "Capital as a Layer Cake: A Systems Approach to Capital and Its Multi-level Structure." Journal of Economic Behavior and Organization 74, no. 1-2: 30-41. https://doi. org/10.1016/j.jebo.2010.01.006.

Hayek, F. A. von. 1945. "The Use of Knowledge in Society." American Economic Review 35, no. 4: 519-30.

Hébert, Robert F., and Albert N. Link. 2006. "Historical Perspectives on the Entrepreneur." Foundations and Trends in Entrepreneurship 2, no. 4: 261-408. https://doi.org/10.1561/0300000008.

Hill, Greg. 2004. “From Hayek to Keynes: G.L.S. Shackle and Ignorance of the Future." Critical Review 16, no. 1: 53-79. https://doi. org/10.1080/08913810408443599.

Jakee, Keith, and Heath Spong. 2003. "Praxeology, Entrepreneurship and the Market Process: A Review of Kirzner's Contribution." Journal of the History of Economic Thought 25, no. 4: 461-86. https://doi.org/10.1080/1 042771032000147515.

Keyhani, Mohammad, and Moren Lévesque. 2016. “The Equilibrating and Disequilibrating Effects of Entrepreneurship: Revisiting the Central Premises." Strategic Entrepreneurship Journal 10, no. 1: 65-88. https:// doi.org/10.1002/sej.1210.

Keynes, John Maynard. 1964. The General Theory of Employment, Interest, and Money. San Diego, Calif.: First Harvest/Harcourt Brace Janovich.

Kirzner, Israel M. 1973. Competition and Entrepreneurship. Chicago: University of Chicago Press. 
1997. "Entrepreneurial Discovery and the Competitive Market Process: An Austrian Approach." Journal of Economic Literature 35, no. 1: 60-85. https://www.jstor.org/stable/2729693.

—. 2005. "Information-Knowledge and Action-Knowledge." Econ Journal Watch 2, no. 1: 75-81.

- 2009. "The Alert and Creative Entrepreneur: A Clarification." Small Business Economics 32, no. 2: 145-52. https://doi.org/10.1007/ s11187-008-9153-7.

Klein, Peter G. 2008. "The Mundane Economics of the Austrian School." Quarterly Journal of Austrian Economics 11, no. 3-4: 165-87. https://doi. org/10.1007/s12113-008-9045-3.

Kor, Yasemin Y., Joseph T. Mahoney, and Steven C. Michael. 2007. "Resources, Capabilities and Entrepreneurial Perceptions." Journal of Management Studies 44, no. 7: 1187-1212. https://doi.org/10.1111/j. 1467-6486.2007.00727.x.

Kuhn, Thomas. 1970. The Structure of Scientific Revolutions. 3d ed. Chicago: University of Chicago Press.

Lachmann, Ludwig M. 1956. Capital and Its Structure. London: Bell and Sons, Ltd.

- 1976. "From Mises to Shackle: An Essay on Austrian Economics and the Kaleidic Society." Journal of Economic Literature 14, no. 1: 54-62.

- 1978. "An Interview with Ludwig Lachmann." Austrian Economics Newsletter 1, no. 3. http://www.mises.org/journals/aen/lachmann.asp.

_. 1986. The Market as an Economic Process. New York: Basil Blackwell.

—_. 1991. "Austrian Economics: A Hermeneutic Approach." Pp. 134-46 in Economics and Hermeneutics, ed. Don Lavoie. New York: Routledge.

Lewin, Peter. 1997. "Hayekian Equilibrium and Change." Journal of Economic Methodology 4, no. 2: 245-66. https://doi.org/10.1080/ 13501789700000017.

- 2001. Review of The Evolution of Austrian Economics: From Menger to Lachmann, by Sandye Gloria-Palermo. Quarterly Journal of Austrian Economics 4, no. 4: 71-82. https://doi.org/10.1007/BF0318423.7. 
—. 2007. "Biography of Ludwig Lachmann (1906-1990): Life and Work." Mises.org, Aug. 1, 2007. https://mises.org/library/ biography-ludwig-lachmann-1906-1990-life-and-work.

Lindlof, Thomas R., and Bryan C. Taylor. 2011. Qualitative Comunication Research Methods. 3d ed. Thousand Oaks, Calif.: Sage Publications.

Loasby, Brian J. 2007. “A Cognitive Perspective on Entrepreneurship and the Firm." Journal of Management Studies 44, no. 7: 1078-1106. https:// doi.org/10.1111/j.1467-6486.2007.00729.x.

Manish, G. P. 2014. "Error, Equilibrium and Equilibration in Austrian Price Theory." Quarterly Journal of Austrian Economics 17, no. 2: 127-53.

Mathews, John A. 2010. "Lachmannian Insights into Strategic Entrepreneurship: Resources, Activities and Routines in a Disequilibrium World." Organization Studies 31, no. 2: 219-44. https://doi. org/10.1177/0170840609347044.

McMullen, Jeffery S. 2010. "Perspective Taking and the Heterogeneity of the Entrepreneurial Imagination." Pp. 113-43 in What Is So Austrian about Austrian Economics?, ed. Roger Koppl, Steven Horwitz, and Pierre Desrochers. Vol. 14 of Advances in Austrian Economics. Bingley, U.K.: Emerald Books. https://doi.org/10.1108/S1529-2134(2010)0000014009.

McMullen, Jeffery S., and Shepherd, Dean A. 2006. "Entrepreneurial Action and the Role of Uncertainty in the Theory of the Entrepreneur." Academy of Management Review 31, no. 1: 132-52. https://doi.org/10.5465/ AMR.2006.19379628.

Merton, Robert K. 2004. "Autobiographical Reflections on The Travels and Adventures of Serendipity." Pp. 230-98 in The Travels and Adventures of Serendipity: A Study in Sociological Semantics and the Sociology of Science, by Robert K. Merton and Elinor Barber. Princeton, N.J.: Princeton University Press.

Meyer, Alan D., Geoffrey R. Brooks, and James B. Goes. 1990. “Environmental Jolts and Industry Revolutions: Organizational Responses to Discontinuous Change." Strategic Management Journal: 11, no. 4: 93-110. https://www.jstor.org/stable/2486672.

Meyer, Alan D., Anne S. Tsui, and C. R. Hinings. 1993. "Configurational Approaches to Organizational Analysis." Academy of Management Journal 36, no. 6: 1175-95. https://doi.org/10.5465/256809.

Mises, Ludwig von. [1949] 1998. Human Action: A Treatise on Economics. Auburn, Ala.: Ludwig von Mises Institute. 
Morgan, Gareth. 1980. "Paradigms, Metaphors, and Puzzle Solving in Organization Theory." Administrative Science Quarterly 25, no. 4: 605-22. https://doi.org/10.2307/2392283.

O'Driscoll, Gerald P., Jr., and Mario J. Rizzo. 1996. The Economics of Time and Ignorance. Abingdon, U.K.: Routledge.

Packard, Mark. 2019. "Entrepreneurship: Toward the Nirvana State of Rest." MISES 7, no. 3. https://doi.org/10.30800/mises.2019.v7.1222.

Packard, Mark D., and Per L. Bylund. 2018. "On the Relationship between Inequality and Entrepreneurship." Strategic Entrepreneurship Journal 12, no. 1: 3-22. https://doi.org/10.1002/sej.1270.

Pe'er, Aviad, and Ilan Vertinsky. 2008. "Firm Exits as a Determinant of New Entry: Is There Evidence of Local Creative Destruction?" Journal of Business Venturing 23, no. 3: 280-306. https://doi.org/10.1016/j. jbusvent.2007.02.002.

Pittaway, Luke. 2005. "Philosophies in Entrepreneurship: A Focus on Economic Theories." International Journal of Entrepreneurial Behavior and Research 11, no. 3: 201-21. https://doi.org/10.1108/13552550510598790.

Polanyi, Michael. 1958. Personal Knowledge: Towards a Post-critical Philosophy. London: Routledge.

Powell, Thomas C., Noushi Rahman, and William H. Starbuck. 2010. "European and North American Origins of Competitive Advantage." Pp. 313-51 in The Globalization of Strategy Research, ed. Joel A. C. Baum and Joseph Lampel. Vol. 27 of Advances in Strategic Management. Bingley, U.K.: Emerald. https:/doi.org/10.1108/ S0742-332220100000027014.

Ripsas, Sven. 1998. "Towards an Interdisciplinary Theory of Entrepreneurship." Small Business Economics 10, no. 2: 103-15. https://doi. org/10.1023/A:1007975330428.

Rothbard, Murray N. 1974. Review of Competition and Entrepreneurship, by Israel M. Kirzner. Journal of Economic Literature 12, no. 3: 902-04.

- 1997. The Logic of Action One: Method, Money, and the Austrian School. Cheltenham, U.K.: Edward Elgar.

- . [1962, 1970] 2009. Man, Economy, and State with Power and Market. 2d scholar's ed. Auburn, Ala.: Ludwig von Mises Institute. 
Salerno, Joseph T. 1993. "Mises and Hayek Dehomogenized." Review of Austrian Economics 6, no. 2: 113-46. https://doi.org/10.1007/BF00842707.

. 1994. "Ludwig von Mises's Monetary Theory in Light of Modern Monetary Thought." Review of Austrian Economics 8, no. 1: 71-115. https://doi.org/10.1007/BF01102317.

Sarkar, M. B., Raj Echambadi, Rajshree Agarwal, and Bisakha Sen. 2006. "The Effect of the Innovative Environment on Exit of Entrepreneurial Firms." Strategic Management Journal 27, no. 6: 519-39. https://doi. org/10.1002/smj.534.

Schulak, Eugen Maris, and Herbert Unterköfler. 2011. The Austrian School of Economics: A History of Its Ideas, Ambassadors, and Institutions. Trans. Arlene Oost-Zinner. Auburn, Ala.: Ludwig von Mises Institute.

Schumpeter, Joseph A. 1934. Theory of Economic Development. Cambridge, Mass.: Harvard University Press.

- 1942. Capitalism, Socialism and Democracy. New York: Harper and Row.

Shackle, G.L.S. 1967. The Years of High Theory: Invention and Tradition in Economic Thought, 1926-1939. Cambridge: Cambridge University Press.

—. 1972. Epistemics and Economics: A Critique of Economic Doctrines. Cambridge: Cambridge University Press.

- 1979. Imagination and the Nature of Choice. Edinburgh: Edinburgh University Press.

Shane, Scott. 1996. "Explaining Variation in Rates of Entrepreneurship in the United States: 1899-1988." Journal of Management 22, no. 5: 747-81. https://doi.org/10.1177/014920639602200504.

—_. 2000. "Prior Knowledge and the Discovery of Entrepreneurial Opportunities." Organization Science 11, no. 4, 448-69. https://doi. org/10.1287/orsc.11.4.448.14602.

. 2012. "Reflections on the 2010 AMR Decade Award: Delivering on the Promise of Entrepreneurship as a Field of Research." Academy of Management Review 37, no. 1: 10-20. https://doi.org/10.5465/ amr.2011.0078.

Shane, Scott, and S. Venkataraman. 2000. "The Promise of Entrepreneurship as a Field of Research." Academy of Management Review 25, no. 1: 217-26. https://doi.org/10.5465/amr.2000.2791611. 
Stake, Robert E. 1995. The Art of Case Study Research. Thousand Oaks, Calif.: Sage Publications.

Tsoukas, Haridimos, and Robert Chia. 2002. “On Organizational Becoming: Rethinking Organizational Change." Organization Science 13, no. 5: 567-82. https://doi.org/10.1287/orsc.13.5.567.7810.

Valliere, Dave. 2013. "Towards a Schematic Theory of Entrepreneurial Alertness." Journal of Business Venturing 28, no. 3: 430-42. https://doi. org/10.1016/j.jbusvent.2011.08.004.

Vaughn, Karen. I. 1994. Austrian Economics in America: The Migration of a Tradition. Cambridge: Cambridge University Press. https://doi. org/10.1017/CBO9780511572142.

Venkataraman, Sankaran. 2004. "Regional Transformation through Technological Entrepreneurship." Journal of Business Venturing 19, no. 1: 153-67. https://doi.org/10.1016/j.jbusvent.2003.04.001.

Weick, Karl E. 1979. The Social Psychology of Organizing. 2d ed. New York: McGraw-Hill. 